\title{
On the Need for Scientific Method in Archaeology: Nämforsen Reconsidered
}

\section{Otto Blehr}

\begin{abstract}
The primary aim of this article is to illustrate empirically what the author regards as a general methodological weakness in archacology. For this purpose the views of Hallström (1960) are compared with those of Baudou (1977) and Ramqvist et al. (1985) on the relationship between the depiction of elks in prehistoric localities in Norrland and elk hunting.
\end{abstract}

Otto Blehr. Department of Social Anthropology. Stockholm University. S-1069I Stockholm. Sweden.

At Nämforsen rapids in the Ångerman river in northern Sweden is one of the largest conglomerations of hunter's rock carvings in Europe. Some 1.375 distinct figures situated on two islets and the adjoining river-banks were identified by Hallström during his visits there between 1907 and 1950. More than half of the carvings he documented depict elks (Alces alces) (1960:283-84, 291), the animal most often found in rock carvings and paintings in northern Sweden. Over the years archaeologists have tried to explain why this is so. In 1984 Ramqvist et al. documented between 60-70 rock carvings, mainly of elk, in the Ume River at Stornorrfors and were struck by the similarities between this location and the one at Nämforsen: Not only do elk figures predominate among the carvings at both localities, but they are also found at the same altitude at the rapids which were formed during land uppheavals about 3500-3000 BC (Renberg \& Segerström 1981). On the basis of these similarities, Ramqvist et al. suggested the following subsistence cycle:

"During the summer periods the lowestlying (major) rapids in the mountain rivers will be a very profitable fishing location while the salmon migrate up the rivers for reproduction. At this season, therefore, many of the hunting-groups in the area gather at these rapids. The main food resource during these summer months is, of course, salmon. When the salmon months are over each group returns to its area of winter activities (maybe via particularly good autumn resources), in which the most important resource is the elk. During the hardest and longest period - the winter the elk thus provides the main game. The depiction of elks in connection with summer sites must therefore be seen in context with the total (annual) subsistence cycle. If there was a critical season, it was the winter and therefore the game of the critical period was the most important of all" (1985:335).

Both the manner in which the elk are depicted and the fact that they usually appear together in bands were seen as decisive:

\begin{abstract}
"The majority of the elks are depicted without antlers, despite the fact that they are often males (i.e. they are depicted in their winter form, since the males lose their antlers in late autumn or early winter). Another winter phenomenon is that elks often gather in large groups, which can sometimes be seen too, on the petroglyph sites" (ibid).
\end{abstract}

Baudou had already earlier suggested that the elk figures without antlers indicate winter hunting. If the hunt was carried out at this time of the year, he argued, how likely was it that 
Nämforsen could have acted as a trap during communal hunting (1976:81-82)? The fact that an extensive dwelling site at Nämforsen lacked bones from elks (ibid:75), led him to ask rhetorically: If Nämforsen served as a great trap during the winter, is it not rather unexpected that no elk bones are to be found among the preserved bones?" (ibid 82). The fact that Hallström already had documented that the rapids at this time of the year were unsuitable as a trap is not mentioned, nor does he discuss his predecessor's conclusion that "the proper catching season at Nämforsen was the summer half of the year, its latter part possibly predominating" (1960:375):

"How the hunt was performed we do not know more than the rapids must have constituted its finishing moment. Probably far-reaching battues provided the preliminaries... A nowadays visitor, being rowed upstream to the islands, might easily visualize the brutal effectivity of the old-time hunters and get visions of small catching boats among whirling dead and halfdead animal bodies" (ibid:377).

To explain why the elk figures predominate among the carvings, Hallström states that this reflects the fact that the elk was the most important animal of hunt (ibid), a view that, as we have seen, Ramqvist et al. share. This was undoubtedly the case, but as an explanation it is too general to be of much value since it does not tell us why we find the elks depicted just at Nämforsen. However, in an earlier work Hallström is more specific when he states that the carvings are meant to lure the animals to their fate in the rapids (1945:31). In other words, the elk depictions had been used in sympathetic magic.

Let this suffice as a short presentation of two dominant and mutually exclusive explanations as to why we find elk figures carved on the rocks at Nämforsen. Both camps, so to speak, consider the elk to have been the most important animal for the hunter-gatherers who carved them. But they differ in their opinion as to the time of the year the hunt took place. And as we have seen, the fact (unknown to Hallström) that no elk bones were found when the large dwelling site at Nämforsen was excavated was of crucial importance when Baudou as well as Ramqvist et al. rejected the notion that these rapids (and for the latter authors, those at Stornorrforsen as well) were used to trap elks during communal hunting. However, they do not discuss whether it is reasonable to believe that the hunters would have used this settlement if they had utilized Nämforsen in connection with communal elk drives. The site is situated on the south side of the river just opposite Notön, and was probably ideal for people engaged in salmon fishing in the nearby rapids. But if they also had used the rapids in connection with elk drives, as Hallström suggested, the situation would have been very different. The animals trapped in the river would inevitably have been carried downstream past the settlement by the strong current. Only once the rapids had lost their force, at that time in a bay of the fiord where they ended, could the elks have been secured by men in boats. The animals that survived the rapids would have been finished off, and together with the already dead ones, towed to the shore. Taking into consideration the size and weight of the elk, the animals would have been skinned and butchered at the places where they were landed. Here, or close by, we accordingly would expect the hunters to have lived. Amazingly enough, as far as I am aware, no systematic search has been carried out along the old shoreline of the bay in an effort to find any settlements once used by the hunters. Yet, Hallström had made it clear that it is here one would have to look:

"It is of great interest that the extremely large numbers of settlements along the shores of the river all the way down from the source-lakes suddenly cease just at Nämforsen. In my unsuccessful searches for carvings downstream from the rapids it is of course conceivable that I have passed by one or several remains of dwelling- 
sites, but no carvings. My explanation is that below the rapids we find ourselves within the region of the ancient bay and that settlements as well as possibly also carvings should not be looked for on the present river-banks but - if they exist at all - on the shores of the bay at that time, that is to say on a level with Nämforsen" (1960:374-375, my italics).

The lack of elk bones among the finds at the settlement opposite Notön was decisive for Baudou and Ramqvist et al. when they argued that communal hunting had not been carried out at Nämforsen (and Stornorrforsen). Whereas Hallström's assumption that the rapids only could have been used to trap elks during the summer half of the year, was based on the fact that ice bridges in winter were formed between the shores as well as the islets in the rapids, and that these would have allowed the animals to have escaped (ibid:375). As to Baudou and Ramqvist et al's disagreement with Hallström as to the time of the year when the hunt was carried out, this rested, as we have seen, on the fact that the bull elks were depicted without antlers. This was an interpretation Hallström did not share. Emphasizing the difficulties involved in carving antlers, he assumed that the carvers had deliberately substituted them with ears (ibid:290).

As I will return to later, neither Baudou nor Ramqvist et al. discussed the hunting techniques that might have been relevant if the elk was procured during the winter. Hallström, on the other hand, outlined the technique he believed had been used by the prehistoric hunters at Nämforsen as well as at the other localities he documented. He therefore deserves credit for setting his data into a much wider context than is usual among archaeologists. When describing the four localities with rock carvings and the six with paintings he, besides the one at Nämforsen, documented in northern Sweden, he emphasized how the local topography was well suited for communal drives ("battues" is the term used by Hallström) (1960:13, 21, 34, 77f, 80, 94 and 120).
What is more, at some of these localities he supported this view with ethological data, showing how the drives were strategically located in relation to the local migration patterns elks were known to follow (ibid:24, 127 , cf. 1943:159). Even though he did not synthesize his findings, Hallström all the same showed a clear link between the depicted elks and the hunting technique using communal drives. He also found this link at Nämforsen. And, as we have seen above, the hunt could only have taken place here during the summer months.

Hallström did not name the season during which the other localities were used, though when discussing them he referred to conditions that are only found during the summer season. And it is quite obvious that at least some of them could only have functioned at this time of the year. For instance, it is no more likely that the rapids at Gärde (ibid:3336) could have been used to trap elks during the winter, than was the case at Nämforsen. It is also apparent that if there are no precipices at the lakesides where the drives end, as is the case at Landverk, Håltbergsudden and Åbosjön (ibid:79, 90, 122-127), it would only have been possible to control the animals' escape when the lakes were not covered with ice. Only once the elks began to swim in their effort to escape their tormentors, would it have been possible for hunters in boats to have successfully outmanoeuvred and killed them (cf. ibid:127). As I discuss below, I think it likely that all the drives took place during the same season. If I am correct in my assumption, this implies that the communal hunting at Hästskotjärn (ibid:1-3, 13), Hällberget (ibid:24), and Fångsjön (ibid:106-108, 120121), must also have been carried out at a time of the year when these lakes could function as "enclosures". And it would also have been during the summer half of the year the elks would have been crippled or killed outright by being driven over the edge of precipices at Glösa (ibid:77-78), Flatruet (ibid:92), and Grannberget (ibid:103). Hallström was aware of this hunting technique, as seen from his suggestion that the animals at Brattberget, 
could have been crushed to death on the rocks below the precipice when trying to escape their tormentors (ibid:19-21). It is worth mentioning that if the elk figures were used in sympathetic magic, this could also hold true for the bears. Since this animal hibernates during the winter, its presence among the carvings and paintings at some of the localities also supports the contention that the communal drives took place during the summer season. This was surely the case at Flatruet, where one of the animals depicted is almost certainty a bear (ibid:95, cf. ibid:78, cf. also Hallström 1938:134-135).

If we accept that carved or painted elks imply use of communal drives at the localities where they are found, then the map of such localities in Ramqvist et al. (1985:314) shows that this form of prehistoric hunting was known over a rather large area of northern Sweden. Why does this hunting technique appear to have been preferred? Might it have been that trapping animals in lakes and rapids, or driving them over the edge of precipices, was considered to be the most successful way of securing prey? Or is it simply that other contemporaneous techniques have left no lasting traces? Ethnographic analogies point to the former explanation. All over the circumpolar region (Spiess 1979:103-137) such forms of communal drives have been favored during the summer half of the year when hunting another ungulate, namely the caribou/wild reindeer (Rangifer Groenlandicus and Rangifer Rangifer), whose behaviour in encounters with humans does not differ essentially from that of the elk's. And yet the fact that communal hunting undoubtedly was carried out during the summer season does not exclude the possibility that the elk could have been hunted during the winter as well. From ethnography we know for instance that the Athapaskanspeaking Kutchin of interior subarctic Alaska during this season traditionally used snares for passive hunting at places where tracks indicated that elks were present, or where the animals were known to come regularly ( $\mathrm{Nel}$ son 1973:109). Another aboriginal technique used at the same time of the year was to drive the elks towards concealed hunters (ibid: 107). However, since these hunting techniques as well as other ones known ethnographically would have left no enduring traces, it is rather pointless to speculate about whether the hunters in question also knew of these ways of securing prey.

Taking all qualifications into account, what can we say with some certainty about the subsistence-settlement system of the prehistoric hunters who carved and painted the elk figures? With Baudou and Ramqvist et al., we might assume that salmon were caught in the rapids at Nämforsen (and Stornorrforsen) as well as at other places, during their summer run upriver to spawn. The fishbones belonging to this species found at the Nämforsen excavation support this hypothesis (Baudou 1977:75). It also seems likely that it was during the summer months that the communal elk drives took place. Hallström, who was more specific, suggested that "its latter part possibly [was] predominating" (1960:375). It might be reasonable to assume that the large rapids at Nämforsen and Stornorrforsen would have been among the most important kill-sites in the fall, and let me also add Vuollerim to this list, where carved elk figures have recently been discovered (Westfal 1991). All of these rapids are in impressive rivers, which made them more advantageous than usual since elk appear to migrate along drainage patterns (Knowlton 1960:164). As we saw above, important migration routes also pass some of the smaller kill-sites. No doubt it would have been advantageous to have hunted the elk during the fall migration, when the numbers were large. At this time of the year the calves have grown, the animals are at their fattest and their hides at the best. With the coming of cold weather the meat could have been saved for winter consumption without risk of spoiling. Ethnographic reports show that the Netsilik and the Copper Eskimos depended on their caches of arctic char and caribou meat while they waited for the sea ice to form so that they could move out on it. At 
the same time, the Eskimos were reluctant to leave the shore as long as their caches lasted. The time of their departure therefore varied from year to year. Only the scarcity of food forced them out onto the ice, where they spent the rest of the winter hunting seal at the blow holes (Jenness 1922; Rasmussen 1931). The ungulate these authors referred to was not elk, but elk meat (together with dried salmon) could also have been an important supplementary resource for our prehistoric hunters during the winter, even if they did not secure the animals (and fish) at this time of the year. I am not necessarily suggesting that the people who hunted with the help of communal drives at Nämforsen and at the other localities where the elk are depicted, followed a yearly subsistence cycle similar to that found among the Netsilik and Copper Eskimos. Admittedly, catching salmon during the spawning run and the elk in the fall during their migration to the winter quarter, do have clear paralles in fishing and hunting among the Eskimos. While a seal bone found at the settlement at Nämforsen (Baudou 1977:75) does indicate that the people who fished there also exploited this animal. The single bone can be what was left over of a seal they had brought with them as provisions on their boat journey to Nämforsen. This suggests that they had engaged in seal hunting at the place they had been during the winter or the spring of the same year (cf. ibid:44ff). A reconstruction of the ecological niche or niches exploited at these times of the year will have to await further archaeological work. The findings from possible settlements along the shoreline of the inlets and bays of the Baltic sea as it then was will be of special interest for what they can tell us (cf. Hallström 1960:375).

Given that Hallström showed years ago that the communal drives were carried out during the summer half of the year at the localities where we find the carved or painted elk figures, my findings here might at first sight seem to be a rather trivial contribution to the ongoing discussion. If not for the fact I have synthesized the comprehensive mass of data he presented in his work (1960) and have been able to strengthen the credibility of his hypothesis. Even more important, I have thereby been able to show the inherited weakness of Baudou's as well as Ramqvist et al's way of reasoning. It should be emphasized that Hallström made this job an easy one for me by presenting data on the local topography as well as on the elk's present day behaviour at many of the sites. That such "non-archaeological" data is of crucial importance for anyone wanting to get an understanding of why the elks are depicted just at the sites we find them, should be quite obvious. A highly relevant question to ask is therefore why such data was ignored by Baudou as well as Ramqvist $e t$ al. When it comes to the latter authors the explanation might simply be that, since they considered Baudou to have "seriously questioned" (Ramqvist et al. 1985:335) Hallström's view that the elks had been trapped in the rapids at Nämforsen, they took this and his other hypothesis for granted. But this can be no more than a secondary explication at best. The real reason must be that like Baudou they did not feel any need to look for data that could refute their hypothesis. Or to be more explicit, the scientific method whereby empirical data is evaluated to see if it can support or refute a hypothesis, is not considered by them. That this is the case is amply illustrated in their works, where we find that only interpretations of data that appear to fit with their winter hunt hypothesis are presented. The fact, for instance, that the communal hunt at some of the localities Hallström documented could only have been carried out during the summer half of the year, is not examined. In fact it is rather telling that Ramqvist et al. do not deal with the smaller localities at all. Nor do they consider the fact that what they look upon as winter bands can just as easily be interpreted as migrating elks, or animals that during communal hunts have been funneled together into groups of sizes comparable to the ones found during that time of the year. Baudou as well as Ramqvist et al. should have questioned their hypothesis about winter hunting for other rea- 
sons too. For instance, is it not rather peculiar that all the smaller inland settlements Baudou (1977) documented were situated at river banks or at lake shores, places where it would have been quite meaningless to camp during winter when water in the form of snow would have been available everywhere?

In my presentation I have ignored the fact that the elk figures alone or together with nonelk figures, could have played a role in other contexts than the one I have dealt with. Neither have I considered the style in which the animals are depicted, which most certainly indicates that the kill sites where the petroglyphs and rock paintings are found had been used by people belonging to different cultural traditions, at the same or at different time periods. What is more, I have not found it necessary for my present line of argument to consider the localities outside Sweden. By discussing different views on the relationship between the depicted elks found in prehistoric localities in Norrland and communal elk hunting, it has primarily been my intention to throw light on what I feel is general methodological weakness in archaeology. To the degree that $\mathbf{I}$ have succeeded in this, it is foremost due to the extraordinary quality of Hallström's archaeological work, and I am consequently greatly indebted to him. It might be considered unfair only to scrutinize the works of Baudou and Ramqvist et al., when I maintain that my criticism of archaeologists is intended to be more general. I accept the point, and I simply point out that the bad luck of these authors merely has to do with the fact that by contrasting their interpretations of data with those of Hallström, I was given the opportunity to illustrate empirically what I consider to be the most serious flaw in Swedish, or for that matter Scandinavian, archaeology.

Finally, some archaeologists might consider me to be too direct and rude. The attitude that disagreement with the hypotheses of other scholars should be passed by without any comment (as was the case with Baudou and Ramqvist et al. on most of the occasions when they had other interpretations of data than Hallström) seems to be the rule among archaeologists. Or alternatively, any divergence of opinion seems to be expected to be given in such a polished and diluted form that the criticism will hardly be felt. I very much disagree on these points. I think that if archaeologists are to be taken seriously as prehistoric ethnographers, as I believe is the wish of many, then the demands on their theories and methods must be just as rigorous as the ones found in scientific anthropology. On the occasions when they fell short of these standards, they should be ready either to take whatever justified criticism they receive, or alternatively limit their research to conventional cultural history. That is, if they do not choose to jump on the post-processual archaeological band wagon, and thereby become free to create their own unique picture of the past (cf. Tilley 1991). 


\section{REFERENCES}

Baudou, E. 1977. Den förhistoriska fångstkulturen i Västernorrland. Västemorrlands förhistoria. 1977:11152. Motala: Västernorrlands läns landsting.

Hallström, G. 1938. Monumental art of northern Europe from the Stone Age. I. The Norwegian localities. Stockholm: Almqvist \& Wiksell.

- 1943. En nyupptäckt svensk hällmålning. Fornvännen $146-161$.

- 1945. Hälristningarna vid Nämforsen. En handledning för besökande. Stockholm.

- 1960. Monumental art of northem Sweden from the Stone Age. II. Nämforsen and other localities. Stockholm: Almqvist \& Wiksell.

Jenness, D. 1922. Life of the Copper Eskimos. Report of the Canadian Arctic Expedition, 1913-18. 12. Ottawa: F. A. Acland.

Knowlton, F. F. 1960. Food habits, movements and populations of moose in the Gravelly Mountains, Montana. The Journal of Wildlife Management. Vol. 24, No. 1. 162-170.

Nelson, R. K. 1973. Hunters of the northern forest. Designs for survival among the Alaskan Kuchin. Chicago. The University of Chicago Press.
Ramqvist, P. H., Forsberg, L. \& Backe, M. 1985. ... and here was an elk too... A preliminary report of new petroglyphs at Stornorrfors, Ume River. In: In Honorem Evert Baudou. Archaeology and Environment 4:313-337.

Rasmussen, K. 1931. The Netsilik Eskimos. Social life and spiritual culture. Report of the Fifth Thule Expedition 1921-24,8(2). Copenhagen: Gyldendals Forlagstrykkeri.

Renberg, I. \& Segerström, U. 1981. The initial points on a shoreline displacement curve for southern Västerbotten, dated by varve-counts of lake sediments. Stria, Vol. 14:174-176.

Spiess, A. E. 1979. Reindeer and caribou humers. An archaeological study. New York. Academic Press. Inc.

Tilley, C. 1991. Material culture and text. The art of ambiguity. London and New York. Routledge.

Westfal, U. 1991. In: ̈̈lg glädjer arkeolog. Svenska Dagbladet, November 9, 1991. 
